ISSN 2179-6750

\title{
Atividade de educação alimentar e nutricional desenvolvida com crianças de 4 a 6 anos de idade no laboratório de desenvolvimento infantil da Universidade Federal de Viçosa-MG: um trabalho de extensão desenvolvido pelo Programa de Educação Tutorial em Nutrição (PET-NUT/UFV)
}

Bruna Clemente Cota, Fernanda Calistene dos Santos Oliveira, Leticia Soares Bueno da Silva, Carolina de Almeida, Jhenifer de Souza Batalha, Juliana Farias de Novaes

\section{Resumo}

A infância é o período em que ocorre a construção dos hábitos alimentares. Uma alimentação adequada nessa fase garante o crescimento e desenvolvimento fisiológico, assim como saúde, bem estar e prevenção de carências nutricionais. O acesso a uma alimentação saudável nesse período é, portanto, essencial, pois as crianças precisam de alimentos mais nutritivos, em proporção ao seu peso, do que os adultos, em virtude do crescimento e desenvolvimento de tecidos e órgãos. Desse modo, atividades de educação alimentar e nutricional nessa faixa etária se mostram de suma importância e a escola se apresenta como um relevante veículo promotor para o desenvolvimento de uma alimentação saudável. O objetivo deste estudo é promover a alimentação saudável no Laboratório de Desenvolvimento Infantil (LDI), através de apresentação de teatro. Trata-se de um estudo transversal realizado na Semana do Dia Mundial da Alimentação Saudável (16 de outubro) em 2015, Viçosa-MG. O teatro foi apresentado a 22 crianças, de ambos os sexos, na faixa etária de 4 a 6 anos, do LDI da Universidade Federal de Viçosa (UFV), junto à presença dos responsáveis. Foi encenada uma história adaptada de "Os Três Porquinhos" no qual se relacionou o tipo de alimentação com a resistência da casa dos porquinhos quanto ao sopro do lobo mal, fazendo alusão ao estado de saúde e qualidade de vida dos porquinhos. O porquinho da casa de palha foi associado à alimentação predominantemente industrializada, rica em açúcares, sódio e gorduras e, por isso, era o mais fraco. O porquinho da casa de madeira alimentava-se com industrializados, e, em partes, com alimentos naturais, como frutas. O porquinho da casa de alvenaria possuía uma alimentação saudável e consumia frutas, hortaliças, cereais, leguminosas, carnes e leite, assim, sendo o único a conseguir manter sua casa de pé. Foi possível observar que as crianças apresentavam conhecimento prévio sobre alimentação saudável, pois elas se manifestaram a respeito das escolhas alimentares dos porquinhos durante a apresentação do teatro. Ao final, notou-se que a proposta foi compreendida, visto que ao serem instigadas em que casa morar, as crianças escolheram a casa de alvenaria. É de extrema importância o envolvimento de toda a comunidade escolar, principalmente dos responsáveis, para que haja efetividade das ações de promoção da alimentação saudável. Tornase necessária uma continuidade no desenvolvimento destas práticas, com atividades lúdicas e divertidas, para a reaprendizagem dos saberes pelas crianças, familiares e professores.

Descritores: Educação alimentar e nutricional; Crianças; Alimentação saudável. 